\title{
Sampling patchily distributed taxa: a case study using cost-benefit analyses for sponges and ascidians in coastal lakes of New South Wales, Australia
}

\author{
P. B. Barnes ${ }^{1, *}$, A. R. Davis ${ }^{1}$, D. E. Roberts ${ }^{2}$ \\ ${ }^{1}$ Institute for Conservation Biology, School of Biological Sciences, University of Wollongong, New South Wales 2522, Australia \\ ${ }^{2}$ BIO-ANALYSIS: Marine, Estuarine \& Freshwater Ecology, 7 Berrys Head Road, Narara, New South Wales 2250, Australia
}

\begin{abstract}
Estuaries worldwide are under increasing threat from human impacts. Because much of their fauna remains unstudied and in many cases undescribed, these systems present real challenges for effective management. In eastern Australia the study of estuarine fauna is often further complicated by its patchy distributions. This is particularly the case for assemblages of sessile invertebrates in coastal saline lakes. This study quantified distributions of sponges and ascidians at a hierarchy of spatial scales in the seagrass meadows of 2 coastal saline lakes in New South Wales, Australia. Nine species of sponge, many of which were undescribed, and 3 species of ascidians were found. Nested analyses of variance were used to identify spatial scales at which variation was significant. Most sponges and ascidians were very patchily distributed at a range of spatial scales from 10s of metres up to 100s of kilometres. The composition of assemblages differed greatly between the 2 lakes. In addition, unlike other published examples of cost-benefit analyses, in the present study very few taxa were widespread over the larger spatial scales. Cost-benefit analyses done to determine the optimal sampling design for future experiments revealed inclusion of patchily distributed taxa in analyses could improve the overall precision of sampling.
\end{abstract}

KEY WORDS: Sponges · Ascidians $\cdot$ Patchiness $\cdot$ Cost-Benefit analyses $\cdot$ Lakes

\section{INTRODUCTION}

Estuaries worldwide are under increasing threat from urbanisation and development (Kennish 2002). Threats come from a myriad of sources, including fishing (Blaber et al. 2000), loss of habitat (Alongi 2002), industrial and urban contamination (Matthiessen \& Law 2002), changes to natural patterns of freshwater flows (Gillanders \& Kingsford 2002) and introduced species (Ruiz et al. 1999). Threats also range in scale (Underwood \& Chapman 1996a), from very large estuary-wide impacts (e.g. changes to the Nile Delta caused by the construction of the Aswan Dam; Stanley \& Warne 1993) to much smaller impacts affecting smaller patches of an estuary (e.g. impacts of boat wash; Bishop 2004). Together, the variety and complexity of threats and range of scales over which impacts may occur provide serious challenges for the management of these systems.

In southeastern Australia, coastal saline lakes and lagoons are a common type of estuary (Roy et al. 2001). These systems are also under extreme pressure with an estimated $85 \%$ of the population living near the coast (Zann 1995). Just 6 of 90 New South Wales (NSW) coastal lakes and lagoons are classified as near pristine, while 12 are considered severely affected by development and a further 17 moderately affected (Healthy Rivers Commission of NSW 2002). Conservation of these lakes will require effective management, which will, in turn, require anthropogenic impacts to be identified and their effects on the ecology of these systems to be understood. While research effort has increased in recent years, the ecology of these systems and the exact nature of the impacts are poorly understood. 
The identification of ecologically important impacts and processes may, however, be a complex and difficult task, particularly against a background of natural variability. A useful starting point in identifying and understanding processes is first to identify patterns and important scales of variability in the distribution of organisms (Underwood et al. 2000). Spatial scales at which significant variation exists often then reveal the scales at which processes are operating. Thus, once appropriate scales have been identified, informed causative models can be examined to understand the relevant processes (Underwood \& Chapman 1996a).

The reliable identification of patterns of distribution of organisms is therefore a key component of a research programme. The design of any study examining patterns of distribution of organisms should include adequate replication at spatial scales at which variation is significant (Morrisey et al. 1992). Inadequate replication at these spatial scales may confound results and reduce the power of statistical tests to detect differences (Underwood \& Chapman 2003). Various strategies and techniques have been developed to help design experiments with appropriate replication to overcome this problem. Such strategies may involve up to 3 stages. First, most rely on having preliminary estimates of variances, which may be obtained from existing data, the literature, or pilot studies. Second, spatial scales at which variation is significant are identified. Third, replication at each spatial scale may then be optimised to obtain a statistical test with a desired level of power or to keep within an allocated budget.

The use of spatially nested designs followed by analyses of variance (ANOVA) has been identified as a powerful technique for identifying scales at which variation is significant (Green 1979, Andrew \& Mapstone 1987, Morrisey et al. 1992, Underwood 1997). Procedures are relatively straightforward for studies examining a single taxon or variable. For studies examining assemblages (i.e. many taxa), optimising sample size is not as straightforward, because there are no procedures available for calculating the power of a multivariate statistical test. In studies comparing assemblages of organisms, it is common practice first to compare whole assemblages (i.e. multivariate sets of data) and then compare specific taxa of interest using univariate techniques (e.g. ANOVA; e.g. Bishop 2004). If preliminary estimates of variances exist, the design of such experiments may be optimised to sample abundances of a particular taxon or another univariate measure using ANOVAs and cost-benefit analyses. An experimental design would then be optimised for certain taxa. It is, of course, unlikely that cost-benefit analyses done for several taxa would all produce the same optimised experimental design (e.g. BenedettiCecchi et al. 1996). Compromises will need to be made in the design of experiments in terms of which taxa to sample most precisely. Ultimately, an experiment should be designed to test the hypotheses of interest. It is, however, sometimes unclear which species of an assemblage are or will be of most interest before the start of a research programme. This is particularly the case for unsurveyed habitats, where taxa may be undescribed or very patchy in their distribution. For example, a recent search of the published literature and unpublished reports found no studies directly relating to sponges, no quantitative descriptions of their distribution, nor any reliable names of species in NSW coastal lakes. It is clear in this case that it is impossible to identify particular species of interest before the start of a research programme. Under these circumstances, the first objective of a research programme will be to identify the species present and describe their basic patterns of distribution.

Detailed case studies examining variation at a hierarchy of spatial scales exist for soft-sediment macrofauna (Morrissey et al. 1992) and intertidal rocky shore assemblages (Underwood \& Chapman 1998) in temperate eastern Australia. Spatial variation in sponge assemblages has been quantified in shallow $(<5 \mathrm{~m}$; Underwood et al. 1991) and deeper (20 to $50 \mathrm{~m}$; Roberts \& Davis 1996) rocky reefs on the open coast of NSW and in semi-enclosed or isolated bodies of water elsewhere in the world (e.g. on mangrove roots in Caribbean lagoons; Farnsworth \& Ellison 1996; tropical estuaries; Kuenen \& Debrot 1995; freshwater lakes; Rader 1984, De Santo \& Fell 1996), but it is unclear whether the extrapolation of such results to the considerably different habitats of seagrasses and soft substrata of relatively shallow and sheltered temperate coastal lakes is likely to be useful.

This paper presents a pilot study examining spatial variation in the distribution of sponges and ascidians in 2 NSW coastal lakes. The aims of this study were 2 -fold. First, to identify spatial scales at which variation was significant and, hence, scales at which important processes may be operating. Second, to assist in the design of further larger scale experiments to examine spatial and temporal changes among and within several NSW coastal lakes. Variation in the abundance of sponge and ascidian fauna was examined at a hierarchy of spatial scales using fully nested sampling designs. When a species was absent from some replicate levels of a spatial scale, variation was examined within the levels of the subsequently nested spatial scale(s) where the species was present. Cost-benefit analyses were used to determine the optimal numbers of locations, sites and replicate samples to be used in future work. 


\section{MATERIALS AND METHODS}

Study sites and sampling methods. Individual sponges and solitary ascidians were counted in relatively shallow ( 0.5 to $2 \mathrm{~m}$ depth) seagrass meadows at a hierarchy of spatial scales in each of 2 saline coastal lakes in New South Wales, Australia, in January and February 2002. Wallis Lake and St Georges Basin (Fig. 1) were chosen as representative of relatively large lakes, moderately affected by development, with entrances that usually remain open to the ocean (Roy et al. 2001). In each lake, 6 locations (kilometres apart), each with 4 sites (100s of metres apart), each with 20 replicate $10 \times 2 \mathrm{~m}$ transects (10s of metres apart) were sampled using SCUBA or by snorkelling depending on depth. Sites were approximately $80 \mathrm{~m}$ in diameter. This design allowed spatial variation to be examined at 4 spatial scales: (1) between lakes 100s of kilometres apart, (2) among locations kilometres apart, (3) among sites 100s of metres apart and (4) among transects within sites 10 s of metres apart. Voucher specimens of sponges were lodged with the Queensland Museum, Brisbane, Australia.

Statistical analyses. Analyses of variance: Three sets of fully nested ANOVAs were used to identify spatial scales at which significant variation occurred. First, 3 variables (the ascidian Styela plicata Lesueur, total numbers of taxa and total numbers of individual sponges) were identified as widespread in both lakes, with non-zero values at most sites in most locations. Each was analysed with a 3-factor (lake, location and site) nested ANOVA, with all factors random.

The remaining taxa were patchily distributed and restricted to a single lake or some locations or sites within a lake. Preliminary examination of these data

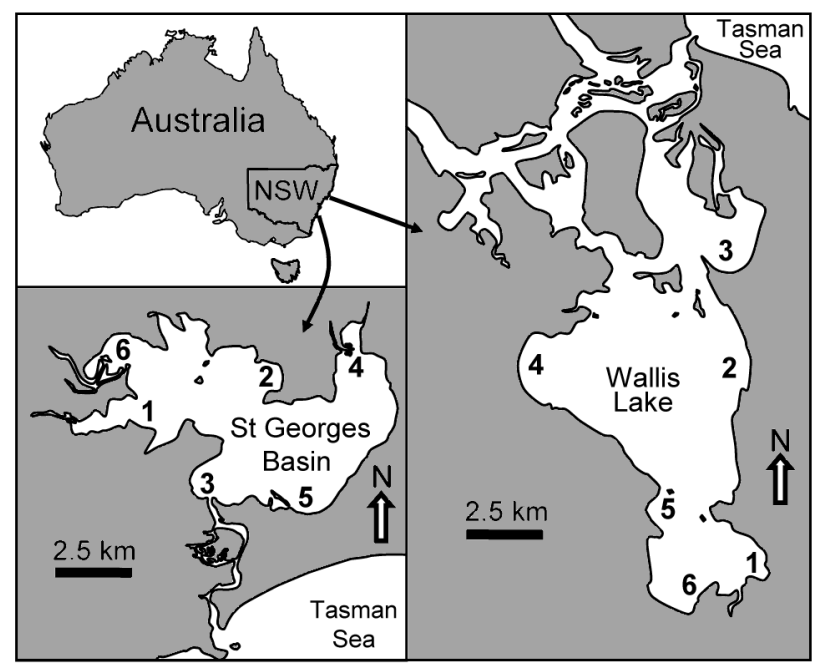

Fig. 1. Locations sampled in Wallis Lake and St Georges Basin on the coast of New South Wales, Australia suggested that 3-factor ANOVAs (as used above) would be inappropriate because of the large numbers of zero values. These species, however, represented the majority of taxa and may presumably occur in other lakes or at subsequent times of sampling. The omission of such taxa from analyses may result in important processes operating at smaller scales and affecting patterns of distribution being overlooked. In the absence of widespread taxa, a broader understanding of spatial variation can be obtained by analysing these patchily distributed taxa in the places where they do occur. Therefore, a second set of ANOVAs was done to test for significant spatial variation among locations and sites within St Georges Basin only, for the solitary ascidian Pyura stolonifera Heller and the sponge Aplysinella cf. rhax. Each was analysed with a 2-factor (location and site) nested ANOVA.

Finally, using the same logic as above, a third set of ANOVAs was done for those species found in only 1 or a few locations in Wallis Lake. Abundances of Halichondria spp., Mycale sp. and Suberites sp. were analysed by a 1-factor (site) ANOVA to test for significant variation among sites in the locations where they occurred. Abundances of very uncommon taxa $\left(<10\right.$ ind. lake $\left.{ }^{-1}\right)$ were not analysed.

The assumption of homogeneity of variances was tested using Cochran's test (Winer et al. 1991). Data were transformed to $\ln (x+1)$ when significant. When transformations did not remove heterogeneity, analyses proceeded, because ANOVA can be robust to deviations from heterogeneity of variances, particularly with fully balanced designs with many independent estimates of variance (Underwood 1981).

In addition, the relative contribution of each spatial scale to the total variation was examined. Variance estimates were calculated for each taxon or derived variable for each spatial scale using ANOVAs of untransformed data (see standard procedures in Underwood 1997).

Cost-benefit analyses: Cost-benefit analyses were done to determine the experimental design appropriate for sampling most taxa most effectively. Analyses were done using variance estimates calculated from ANOVAs of untransformed data (see standard procedures described in Winer et al. 1991, Underwood 1997). The limiting cost was time. Given the relatively large amount of travelling and preparation time needed to get to a lake, it was inefficient for lakes to be sampled in fractions of days. Thus, it was important that a lake could be sampled within a single day. Therefore, the number of replicate locations, sites and transects were optimised to keep within a budget of $1 \mathrm{~d}$ lake $^{-1}$ (i.e. $360 \mathrm{~min}$ on the water, excluding travelling to and from a lake). The average time to sample 1 transect was $2 \mathrm{~min}$, time to manoeuvre the boat between 
sites was $10 \mathrm{~min}$ and between locations was $20 \mathrm{~min}$. Cost-benefit analyses were done only within levels of spatial scales in which taxa were present.

The number of replicate transects per site (n) was determined using:

$$
n=\sqrt{\frac{S_{\mathrm{e}}^{2} \times C_{b}}{S_{\mathrm{B}(\mathrm{A})}^{2} \times C_{n}}}
$$

The number of replicate sites per location $(b)$ was determined using:

$$
b=\sqrt{\frac{S_{\mathrm{B}(\mathrm{A})}^{2} \times C_{a}}{S_{\mathrm{A}}^{2} \times C_{b}}}
$$

The optimal number of locations per lake (a) was then determined as:

$$
a=\frac{\text { Cost of lake }}{C_{a}+b C_{b}+b n C_{n}}
$$

where $S_{\mathrm{e}}^{2}$ is the estimated variance among transects, $S_{\mathrm{B}(\mathrm{A})}^{2}$ is the estimated variance among sites, $S_{\mathrm{A}}^{2}$ is the estimated variance among locations, $C_{a}$ is the cost per location, $C_{b}$ is the cost per site and $C_{n}$ is the cost per transect.

\section{RESULTS}

\section{List of taxa}

In Wallis Lake, 9 species of sponges and 3 species of ascidians were found and, in St Georges Basin, 2 species of sponges and 2 species of ascidians (Table 1). Of the 9 species of sponges collected, only 2 could be

\begin{tabular}{|c|c|c|c|c|c|c|c|c|c|c|c|c|}
\hline \multirow[t]{2}{*}{ Taxon } & \multicolumn{6}{|c|}{ St Georges Basin } & \multicolumn{6}{|c|}{ Wallis Lake } \\
\hline & 1 & 2 & 3 & 4 & 5 & 6 & 1 & 2 & 3 & 4 & 5 & 6 \\
\hline \multicolumn{13}{|l|}{ Porifera } \\
\hline Aplysilla cf. sulphurea & - & - & - & - & - & - & + & - & - & - & - & - \\
\hline Aplysinella cf. rhax & + & + & - & + & + & + & - & - & - & - & - & - \\
\hline Halichondria spp. & + & - & + & + & + & + & - & - & + & - & - & - \\
\hline Haliclona sp. 1 & - & - & - & - & - & - & - & - & + & - & - & - \\
\hline Haliclona sp. 2 & - & - & - & - & - & - & - & - & - & + & - & - \\
\hline Dysidea sp. & - & - & - & - & - & - & + & - & - & - & - & - \\
\hline Mycale sp. & - & - & - & - & - & - & + & - & - & - & + & - \\
\hline Raspailia sp. & - & - & - & - & - & - & - & - & - & - & + & - \\
\hline Suberites sp. & - & - & - & - & - & - & + & + & - & - & - & + \\
\hline \multicolumn{13}{|l|}{ Ascidiacea } \\
\hline Microcosmus sp. & - & - & - & - & - & - & + & - & + & - & - & - \\
\hline Pyura stolonifera & + & + & + & + & + & + & - & - & + & + & - & - \\
\hline Styela plicata & + & + & - & + & + & + & + & + & + & + & + & + \\
\hline
\end{tabular}

Table 1. Taxa found in each location (1 to 6) in St Georges Basin and/or Wallis Lake. +: species present; -: not present identified to species level. The remainder were either undescribed or presently unable to be assigned to a known taxa, given the plethora of taxa in the older literature the identities of which still remain a mystery (Hooper \& Wiedenmayer 1994). Because it was not possible to distinguish among species of Halichondria in the field, all species in this genus were simply recorded as Halichondria spp.

The taxa identified differed markedly between the 2 lakes, with 2 of the 3 ascidians, Styela plicata and Pyura stolonifera, but only 1 sponge, Halichondria spp., found in both lakes (Table 1). In addition, patterns of presence/absence of individual taxa within lakes differed greatly between the 2 lakes. While Aplysinella cf. rhax, Halichondria spp., P. stolonifera and S. plicata were widespread throughout St Georges Basin, most taxa in Wallis Lake were found in 1 or a limited number of locations, with the exception of the introduced S. plicata.

\section{Spatial scales of variation}

At the scale of lake (100s of kilometres apart), there was no significant variation in mean numbers of taxa, total numbers of individual sponges, nor abundances of Styela plicata per transect (Table 2, Fig. 2). In contrast, there was significant variation of these variables at the smaller scales of location (kilometres apart) and site (100s of metres apart) within lakes (Table 2, Fig. 2). Similarly, in St Georges Basin, there was significant variation in the abundances of Aplysinella cf. rhax and Pyura stolonifera at the scales of location and site (Table 3, Fig. 2).

In Wallis Lake, preliminary examination of raw data for each taxon showed obvious patchiness at the scale of location (kilometres apart) (Table 1, Fig. 2). ANOVAs were therefore done only within locations where specific taxa occurred and where abundances were large enough for ANOVA to be appropriate. Variation among sites was not significant for Halichondria spp. (Location 3), Mycale sp. (Location 5), or Suberites sp. (Location 1). In contrast, there was significant variation among sites for Mycale sp. at Location 1 (Table 4, Fig. 2).

Estimates of variance components for each variable are shown in Table 5. Caution should be used in the interpretation of variance components across taxa because the size of the residual variance will affect the contribution of each spatial scale to the total variance (Morrisey et al. 1992, Underwood \& 
Table 2. ANOVAs to examine variation for selected variables between and within St Georges Basin and Wallis Lake. ns: not significant; ${ }^{* * *} \mathrm{p}<0.001$; Lo: location; La: lake

\begin{tabular}{|c|c|c|c|c|c|c|c|c|c|c|}
\hline \multirow{2}{*}{$\begin{array}{l}\text { Source of } \\
\text { variation }\end{array}$} & \multirow[t]{2}{*}{ df } & \multicolumn{3}{|c|}{ Total no. of taxa } & \multicolumn{3}{|c|}{ Total no. of individual sponges } & \multicolumn{3}{|c|}{ No. of Styela plicata } \\
\hline & & MS & $F$ & $\mathrm{p}$ & MS & $F$ & $\mathrm{p}$ & MS & $F$ & $\mathrm{p}$ \\
\hline Lake & 1 & 7.32 & 0.59 & ns & 32.53 & 1.20 & ns & 104.46 & 1.06 & ns \\
\hline Location (La) & 10 & 12.35 & 8.79 & $* * *$ & 27.00 & 5.04 & $* * *$ & 98.66 & 10.78 & $* * *$ \\
\hline Site (Lo(La)) & 36 & 1.40 & 12.29 & $* * *$ & 5.36 & 11.76 & $* * *$ & 9.16 & 29.86 & *** \\
\hline Residual & 912 & 0.11 & & & 0.46 & & & 0.31 & & \\
\hline Transformation & & $\operatorname{Ln}(x+1)$ & & & $\operatorname{Ln}(x+1)$ & & & $\operatorname{Ln}(x+1)$ & & \\
\hline
\end{tabular}
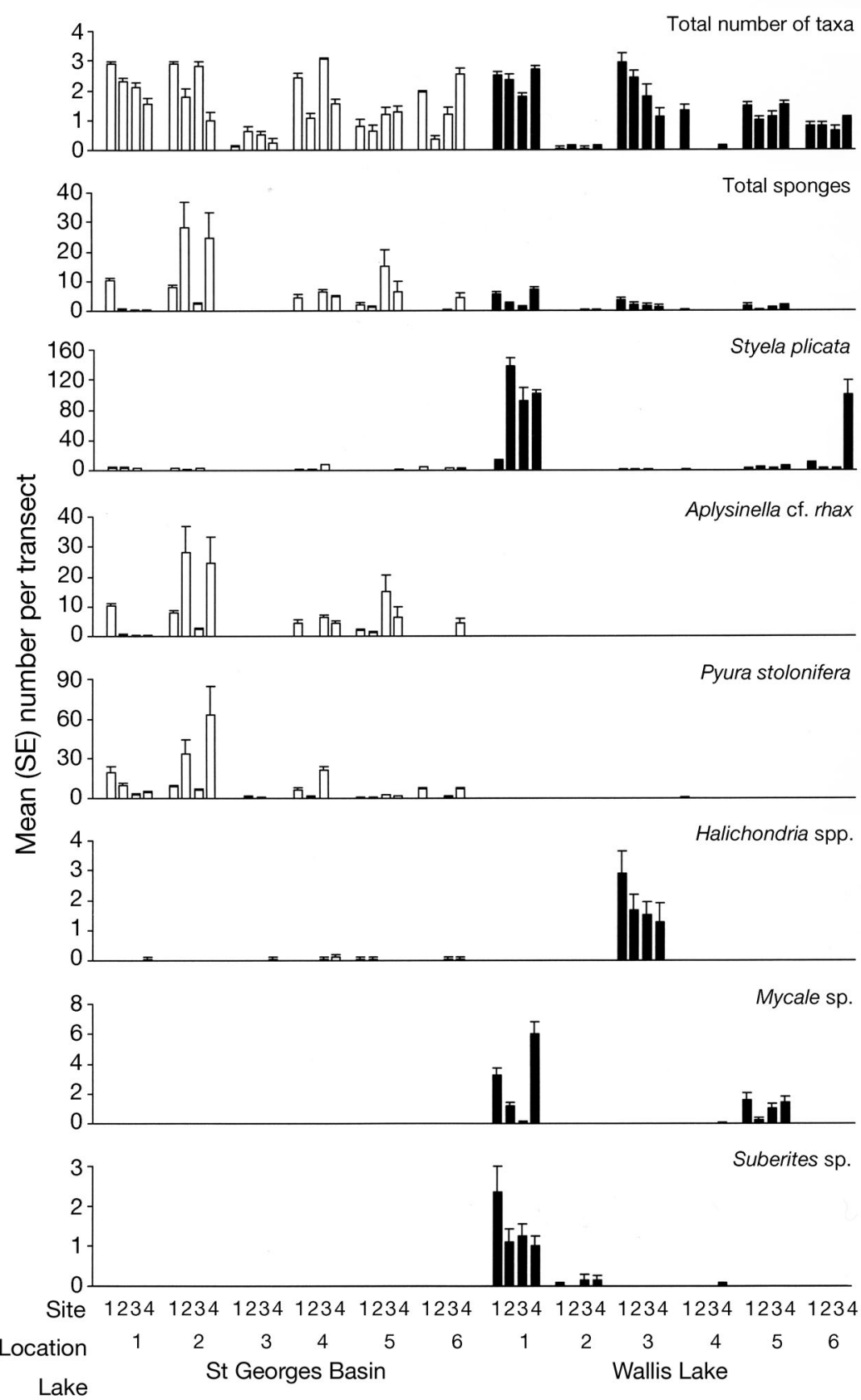

Fig. 2. Mean (SE) numbers per transect $(n=20)$ at each site
Petraitis 1993). When the proportion of the residual variance differs among taxa, proportions of other spatial scales should not be compared across taxa. The size of residual variance, however, will not affect the ratio among other variance components within a taxon (Underwood \& Petraitis 1993). Therefore, ratios of variance estimates can be compared. In the present study, there was considerable residual variance (i.e. among transects within sites) for all taxa examined. The proportion of residual variance ranged from 27 to $73 \%$ for variables examined in both lakes, 74 to $76 \%$ for Aplysinella cf. rhax and Pyura stolonifera in St Georges Basin and 43 to $98 \%$ for Suberites sp., Mycale sp. and Halichondria spp. in Wallis Lake. These relatively large contributions suggest that there was also considerable patchiness at small spatial scales of 10 s of metres within sites.

In addition, variance components confirm that there was little variation between lakes for number of taxa, total number of sponges and Styela plicata, but most variation was at the smaller spatial scales of locations, sites and transects.

\section{Optimising replication (cost-benefit analyses)}

Appropriate replication was determined in 3 stages. First, cost-benefit analyses were done to determine the optimal replication for comparisons among lakes. Analyses were done for numbers of taxa, total numbers of sponges and for Styela plicata using data from both lakes and for Aplysinella cf. 
Table 3. ANOVAs to examine variation among locations and sites for abundances of Aplysinella cf. rhax and Pyura stolonifera in St Georges Basin. ${ }^{* * *} \mathrm{p}<0.001 ;{ }^{* *} \mathrm{p}<0.01 ;{ }^{*} \mathrm{p}<0.05$; Lo: location

\begin{tabular}{|c|c|c|c|c|c|c|c|}
\hline \multirow{2}{*}{$\begin{array}{l}\text { Source of } \\
\text { variation }\end{array}$} & \multirow[t]{2}{*}{$\mathrm{df}$} & \multicolumn{3}{|c|}{ A. cf. rhax } & \multicolumn{3}{|c|}{ _ P. stolonifera } \\
\hline & & MS & $F$ & $\mathrm{p}$ & MS & $F$ & $\mathrm{p}$ \\
\hline Location & 5 & 30.63 & 3.39 & * & 41.92 & 4.35 & ** \\
\hline Site (Lo) & 18 & 9.04 & 13.68 & **** & 9.64 & 11.87 & *** \\
\hline Residual & 456 & 0.66 & & & 0.81 & & \\
\hline \multicolumn{2}{|c|}{ Transformation } & $\operatorname{Ln}(x+1$ & & & $\operatorname{Ln}(x+1$ & & \\
\hline
\end{tabular}

lake $^{-1}$ (i.e. 60 min location ${ }^{-1}$ ). For Option 1 (10 locations lake $\left.{ }^{-1}\right)$, although there were originally differences among species in the numbers of sites (0.4 to 1.2) and transects (2.0 to 15.4), when the numbers were rounded to stay within the time budget, the design became the same for all species (1 site and 3 transects location $^{-1}$; Table 6). For Option 2 (6 locations lake ${ }^{-1}$ ), the design varied from 1 to 3 sites location ${ }^{-1}$ and 15 to 2 transects site ${ }^{-1}$ (Table 6).

Finally, to determine the best compromise in replication, the precision of estimating the means of each design was compared among the different variables. Precision was calculated as the estimated standard error of the mean (SEM, number per sample) and expressed as a percentage. The estimated SEM was calculated as the square root of the estimated variance of the means, $V$, where:

$$
V=\frac{\left(S_{\mathrm{e}}^{2}+n \times S_{\mathrm{B}(\mathrm{A})}^{2}+n \times b \times S_{\mathrm{A}}^{2}\right)}{n \times b \times a}
$$

for calculating SEM per lake and:

$$
V=\frac{\left(S_{\mathrm{e}}^{2}+n \times S_{\mathrm{B}(\mathrm{A})}^{2}\right)}{n \times b}
$$

for calculating SEM per location.

At the scale of location, the precision of sampling patchily distributed taxa (Suberites sp., Mycale sp. and Halichondria spp.) was greatly improved by using 2 sites and 5 transects compared to 1 site and 3 transects

Table 4. ANOVAs to examine variation among sites within specified locations in Wallis Lake for each of Halichondria spp.,

\begin{tabular}{|c|c|c|c|c|c|c|c|c|c|c|c|c|c|}
\hline \multirow{2}{*}{$\begin{array}{l}\text { Source of } \\
\text { variation }\end{array}$} & \multirow[t]{2}{*}{ df } & \multicolumn{3}{|c|}{ Halichondria spp. (L3) } & \multicolumn{3}{|c|}{ — Mycale sp. (L1) — } & \multicolumn{3}{|c|}{ — Mycale sp. (L5) - } & \multicolumn{3}{|c|}{ —Suberites sp. (L1) } \\
\hline & & MS & $F$ & $\mathrm{p}$ & MS & F & $\mathrm{p}$ & MS & F & $\mathrm{p}$ & MS & $F$ & $\mathrm{p}$ \\
\hline Site & 3 & 10.82 & 1.42 & ns & 11.54 & 38.19 & $* * *$ & 6.77 & 2.48 & ns & 0.44 & 1.04 & ns \\
\hline Residual & 76 & 7.59 & & & 0.30 & & & 2.73 & & & 0.42 & & \\
\hline \multicolumn{2}{|c|}{ Transformation } & None & & & $\operatorname{Ln}(x+1)$ & & & None & & & $\operatorname{Ln}(x+1)$ & & \\
\hline
\end{tabular}
Mycale sp. and Suberites sp. Locations are indicated in parentheses. ns: not significant; ${ }^{* * *} p<0.001$

Table 5. Variance estimates derived from ANOVA for selected variables calculated from untransformed data. Locations are indicated in parentheses. -: variances were not calculated at that spatial scale; Lo: location; La: lake

\begin{tabular}{|lccccccccc|}
\hline $\begin{array}{l}\text { Source } \\
\text { of variation }\end{array}$ & $\begin{array}{c}\text { Total no. } \\
\text { of taxa }\end{array}$ & $\begin{array}{c}\text { Total no. } \\
\text { of sponges }\end{array}$ & $\begin{array}{c}\text { Styela } \\
\text { plicata }\end{array}$ & $\begin{array}{c}\text { Aplysinella } \\
\text { cf. rhax }\end{array}$ & $\begin{array}{c}\text { Pyura } \\
\text { stolonifera }\end{array}$ & $\begin{array}{c}\text { Suberites } \\
\text { sp. (L1) }\end{array}$ & $\begin{array}{c}\text { Mycale } \\
\text { sp. (L1) }\end{array}$ & $\begin{array}{c}\text { Mycale } \\
\text { sp. (L5) }\end{array}$ & $\begin{array}{c}\text { Halichondria } \\
\text { spp. (L3) }\end{array}$ \\
\hline Lake & 0.03 & 4 & 68 & - & - & - & - & - & - \\
Location (La) & 0.53 & 12 & 478 & 22 & 67 & - & - & - & - \\
Site (Lo(La)) & 0.28 & 16 & 405 & 31 & 119 & 0.23 & 6.53 & 0.20 & 0.16 \\
Residual & 0.50 & 86 & 344 & 169 & 537 & 3.24 & 5.00 & 2.73 \\
\hline
\end{tabular}


Table 6. Replication at each spatial scale derived from cost-benefit analyses for sampling sponges and ascidians. Values in parentheses have not been rounded. Numbers in bold have been rounded to whole units of sampling. In cases where there was a choice between rounding up or down, the replication that produced the more precise estimate of the mean is given. S: site;

$$
\text { L: location }
$$

\begin{tabular}{|c|c|c|c|c|c|c|c|c|c|}
\hline & \multicolumn{3}{|c|}{ Both lakes } & \multicolumn{2}{|c|}{ —St Georges Basin — } & \multirow[b]{2}{*}{$\begin{array}{l}\text { Suberites } \\
\text { sp. (L1) }\end{array}$} & \multicolumn{2}{|c|}{ Wallis Lake - } & \multirow[b]{2}{*}{$\begin{array}{l}\text { Halichondria } \\
\text { spp. (L3) }\end{array}$} \\
\hline & $\begin{array}{l}\text { No. of } \\
\text { taxa }\end{array}$ & Sponges & $\begin{array}{l}\text { Styela } \\
\text { plicata }\end{array}$ & $\begin{array}{l}\text { Aplysinella } \\
\text { cf. rhax }\end{array}$ & $\begin{array}{c}\text { Pyura } \\
\text { stolonifera }\end{array}$ & & $\begin{array}{l}\text { Mycale } \\
\text { sp. (L1) }\end{array}$ & $\begin{array}{l}\text { Mycale } \\
\text { sp. (L5) }\end{array}$ & \\
\hline Locations & $10(10.0)$ & $6(6.0)$ & $11(10.6)$ & $6(6.7)$ & $6(6.0)$ & \multicolumn{4}{|c|}{ Option 1: 10 locations lake la $^{-1}$} \\
\hline Sites (L) & $1(1.0)$ & $2(1.6)$ & $1(1.3)$ & $2(1.7)$ & $2(1.9)$ & $1(0.6)$ & $1(1.2)$ & $1(0.6)$ & $1(0.4)$ \\
\hline Transects $(\mathrm{S}(\mathrm{L}))$ & $3(3.0)$ & $5(5.2)$ & $2(2.1)$ & $5(5.3)$ & $5(4.8)$ & $3(8.4)$ & $3(2.0)$ & $3(8.2)$ & $3(15.4)$ \\
\hline Locations & & & & & & \multicolumn{4}{|c|}{ Option 2: 6 locations lake ${ }^{-1}$} \\
\hline Sites (L) & & & & & & $2(1.5)$ & $3(2.9)$ & $2(1.5)$ & $1(1.0)$ \\
\hline Transects (S(L)) & & & & & & $5(8.4)$ & $2(2.0)$ & $5(8.2)$ & $15(15.4)$ \\
\hline
\end{tabular}

(Table 7). In comparison, there was only a relatively small loss in precision of the mean at the scale of lake when sampling number of taxa and Styela plicata with 6 locations, 2 sites and 5 transects compared to 10 locations and 3 transects. Therefore, it was concluded that the best allocation of resources would be to use 6 locations, 2 sites and 5 transects lake ${ }^{-1}$.

\section{DISCUSSION}

Two key patterns of distribution of sponges and ascidians in coastal lakes are highlighted by this study. First, most of the sponges and ascidians were clearly very patchily distributed at a range of spatial scales from 10 s of metres up to 100 s of kilometres, which appears common for many species of sponges and ascidians in other habitats (Roberts \& Davis 1996, Ferdeghini et al. 2000, Hooper \& Kennedy 2002, Hooper et al. 2002). Second, few taxa were widespread over the larger spatial scales. While similar patterns have been found in other enclosed bodies of water (e.g. Kuenen \& Debrot 1995), the organisation of assemblages in these lakes appears fundamentally different to those on the open coast, where assemblages of sponges and ascidians usually consist of several patchy but widespread species and numerous very uncommon taxa (e.g.

Table 7. Precision (\%) of estimating means measured as the standard error of the mean for selected variables at the scales of lake and location, using different numbers of locations, sites and transects

\begin{tabular}{|c|c|c|c|c|c|c|}
\hline \multirow{3}{*}{$\begin{array}{l}\text { Numbers of } \\
\text { locations, } \\
\text { sites, } \\
\text { transects }\end{array}$} & \multirow{2}{*}{\multicolumn{2}{|c|}{$\begin{array}{l}\text { Precision at the } \\
\text { scale of lake }\end{array}$}} & \multicolumn{4}{|c|}{ Precision at the scale of location } \\
\hline & & & Suberites & Mycale & Mycale & Halichondria \\
\hline & $\begin{array}{l}\text { No. of } \\
\text { taxa }\end{array}$ & $\begin{array}{l}\text { Styela } \\
\text { plicata }\end{array}$ & sp. (L1) & sp. (L1) & sp. (L5) & spp. (L3) \\
\hline $10,1,3$ & 24.6 & 92.9 & 80.3 & 108.0 & 100.4 & 89.9 \\
\hline $6,2,5$ & 27.2 & 101.5 & 46.5 & 73.2 & 58.2 & 50.2 \\
\hline
\end{tabular}

Wilkinson \& Evans 1989, Farnsworth \& Ellison 1996, Roberts \& Davis 1996, Rutzler et al. 2000).

Such variability suggests there may be many different processes operating and influencing these patterns at a range of scales from a few metres to an entire lake (Underwood \& Chapman 1996b). In addition, patterns were complex and not consistent between lakes, suggesting different processes may be operating in different lakes. Numerous mechanisms, including predation (Wulff 2000), availability of substrata to settle on (Keough 1984), water quality (Burns \& Bingham 2002), hydrodynamics (Guichard \& Bourget 1998), competition, dispersal and recruitment (Farnsworth \& Ellison 1996) have been proposed and examined to explain these distributions.

At the largest spatial scale of lakes (100s of kilometres apart), while the mean number of taxa and mean abundance of sponges per transect did not differ, the composition of assemblages differed greatly between the 2 lakes. Only 1 of 9 genera of sponges was found in both lakes, and these (Halichondria spp.) may be different species. Differences between lakes point to processes operating at large spatial scales of the entire lake and/or region. Although little is known of many of the taxa found in this study, it is logical to suggest different species may have different tolerances to the physiological stresses imposed by these environments and hence different distributions. For example, water quality can vary greatly among NSW lakes (Pollard 1994a, West \& Jones 2000). Large-scale floods can dramatically change physical variables such as salinity, temperature, turbidity and $\mathrm{pH}$ and affect entire estuaries and assemblages of animals (Moverley et al. 1986). Further, the magnitude and duration of changes after input of freshwater may vary greatly among different NSW coastal 
lakes (e.g. Pollard 1994a). Similarly, the regime of opening and closing of entrances of NSW lakes is known to affect water quality, which can be correlated with the distribution of some organisms (Dye \& Barros 2005). Differences in species composition may also be due to limited dispersal between lakes. Dispersal may be limited because: (1) coastal lakes in NSW are separated by 10 s to 100 s of kilometres of open coast, (2) it appears that the distributions of many of these sponges are not continuous along the coast and may be restricted to lakes or estuaries (P. B. Barnes unpubl. data) and (3) many sponges have short dispersal distances (Zea 1993, Farnsworth \& Ellison 1996, Maldonado \& Young 1996, but see Davis et al. 1996).

Patchiness was also clear at smaller spatial scales from 10 s and 100 s of metres to kilometres apart within lakes. This was most evident in Wallis Lake where only 2 of the 8 species of sponge were found in $>1$ location. Nevertheless, some species were relatively abundant at some places. Similarly, the abundances of those more widespread taxa were significantly variable within the spatial scales in which they occurred. Again, numerous processes have been proposed to explain smaller-scale patterns. For example, abiotic factors which may affect sponges such as sedimentation rates (Burns \& Bingham 2002) and turbidity (Bell \& Barnes 2000) are known to differ among areas within lakes kilometres apart (Roberts 2001, Sloss et al. 2004). Larval recruitment and small dispersal distances have been proposed as important in explaining aggregated patterns of distribution of epibionts (including sponges and ascidians) over relatively small scales of metres to $100 \mathrm{~s}$ of metres (Farnsworth \& Ellison 1996). Predation by fish has been found to play a key role in structuring assemblages of sponges in some habitats (Pawlik 1998, Wulff 2000), and abundances of fishes are often patchy and differ among habitats within and among NSW lakes (Pollard 1994b).

The shallow areas sampled in these lakes are often a mosaic of patches of different species of seagrasses and macroalgae and patches of bare sediment (West et al. 1985, Cummins et al. 2004b), which vary over scales of metres to kilometres. Such patchiness in habitat may have a number of consequences for the distribution of sponges and ascidians. For example, sponges and ascidians were found attached to a variety of surfaces, including seagrasses, macroalgae and fragments of shells, and unattached on top of patches of sediment. Small-scale patchiness in the distribution of sponges and ascidians may therefore be related to the availability of suitable substratum on which to settle (Keough 1984). In addition, assemblages of potential predators may differ among types of vegetation and, therefore, affect distributions of sponges and ascidians. Overall, it is likely that many processes are interacting to influence patterns of distribution.
Greater understanding of the ecology of sponges and ascidians in coastal lakes and, hence, long-term conservation will best be achieved by experimental examination of the processes causing small- and large-scale patterns of variation. Also, because patterns of distribution varied greatly among species, further experiments should include examination of specific species (Cummins et al. 2004a). However, because assemblages of sponges and ascidians in these habitats are virtually unknown, it would be beneficial first to test the generality or otherwise of these patterns through time and among different lakes. The findings of this study have several important implications for the design of such research programmes.

At the scale of lake, although there were no significant differences in the mean number of taxa, individual sponges, or Styela plicata per transect, there were obvious differences in the composition of assemblages between lakes. Two-thirds of the taxa were exclusively found in one or the other lake. Wallis Lake had more taxa (11) compared to St Georges Basin (4) and taxa were widespread throughout St Georges Basin, but in Wallis Lake most were restricted to 1 or a few locations. Such obvious differences emphasise the need to include adequate replication at the scale of lake for studies examining differences in composition of assemblages among large spatial scales (e.g. regions of coast) or types of lake (e.g. urbanised versus relatively pristine, open versus intermittently open or closed to the sea). For such comparisons, inclusion of sampling at a hierarchy of spatial scales will further improve the power of tests for differences (Morrisey et al. 1992). Further, adequate replication at the smaller scales of 10 s and 100s metres and kilometres will be needed to ensure differences between lakes are not masked by significant small-scale variation. Very patchy distributions at the scale of locations kilometres apart (as in Wallis Lake) also have important consequences for finding sponges in a lake. The number of locations sampled will determine the probability of a particular species being found. For example, Mycale sp. was widespread in only 2 of the 6 locations in Wallis Lake. Logically, the probability of sampling at least 1 location with Mycale sp. will increase with the number of locations sampled (for theory on sampling rare species see Kovalak et al. 1986, Green \& Young 1993).

In the present study, unlike other published examples of spatial variation and cost-benefit analyses (Kennelly \& Underwood 1985, Morrisey et al. 1992, Benedetti-Cecchi et al. 1996, Bartsch et al. 1998), there were very few taxa widespread over all spatial scales. Such studies quite appropriately chose to analyse taxa that were 'consistently present' (Morrisey et al. 1992), because they presumably represented a large proportion of and were therefore representative of the assem- 
blage. In contrast, this study found that it was often the patchily distributed taxa that represented the largest proportion of the assemblage. In this case, it was important to optimise sampling designs for those taxa. It should not be assumed that derived variables such as total number of taxa are appropriate surrogates for designing experiments to sample individual species. Rather, if the aim of the sampling programme is to sample many taxa as precisely as possible, designs can be improved by including patchily distributed taxa in cost-benefit analyses. In this study, it was found that the selection of a sampling design that led to relatively large increases in precision of sampling patchily distributed taxa, resulted in only relatively small compromises in the precision of sampling widespread variables.

Acknowledgements. We thank J. Grayson, A. Ferguson and R. Kucera for assistance with fieldwork; J. Hooper and the staff of the Queensland Museum for identification of sponges; and N. Knott and 2 anonymous referees for useful comments on the manuscript. This study was supported by funds from Wyong Shire Council and an Australian Postgraduate Research Award (Industry) to P.B.B. This is Contribution Number 261 from the Ecology and Genetics group at the University of Wollongong.

\section{LITERATURE CITED}

Alongi DM (2002) Present state and future of the world's mangrove forests. Environ Conserv 29:331-349

Andrew NL, Mapstone BD (1987) Sampling and the distribution of spatial pattern in marine ecology. Oceanogr Mar Biol Annu Rev 25:9-90

Bartsch LA, Richardson WB, Naimo TJ (1998) Sampling benthic macroinvertebrates in a large flood-plain river: considerations of study design, sample size, and cost. Environ Monit Assess 52:425-439

Bell JJ, Barnes DKA (2000) The distribution and prevalence of sponges in relation to environmental gradients within a temperate sea lough: inclined cliff surfaces. Divers Distrib 6:305-323

Benedetti-Cecchi L, Airoldi L, Abbiati M, Cinelli F (1996) Estimating the abundance of benthic invertebrates: a comparison of procedures and variability between observers. Mar Ecol Prog Ser 138:93-101

Bishop MJ (2004) A posteriori evaluation of strategies of management: the effectiveness of no-wash zones in minimizing the impacts of boat wash on macrobenthic infauna. Environ Manag 34:140-149

Blaber SJM, Cyrus DP, Albaret JJ, Ching CV and 7 others (2000) Effects of fishing on the structure and functioning of estuarine and nearshore ecosystems. ICES J Mar Sci 57: 590-602

Burns DO, Bingham BL (2002) Epibiotic sponges on the scallops Chlamys hastata and Chlamys rubida: increased survival in a high-sediment environment. J Mar Biol Assoc UK 82:961-966

Cummins SP, Roberts DE, Ajani P, Underwood AJ (2004a) Comparisons of assemblages of phytoplankton between openwater and seagrass habitats in a shallow coastal lagoon. Mar Freshw Res 55:447-456
Cummins SP, Roberts DE, Zimmerman KD (2004b) Effects of the green alga Enteromorpha intestinalis on macrobenthic and seagrass assemblages in a shallow coastal estuary. Mar Ecol Prog Ser 266:77-87

Davis AR, Ayre DJ, Billingham MR, Styan CA, White GA (1996) The encrusting sponge Halisarca laxus: population genetics and association with the ascidian Pyura spinifera. Mar Biol 126:27-33

De Santo EM, Fell PE (1996) Distribution and ecology of freshwater sponges in Connecticut. Hydrobiologia 341:81-89

Dye AH, Barros F (2005) Spatial patterns in meiobenthic assemblages in intermittently open/closed coastal lakes in New South Wales, Australia. Estuar Coast Shelf Sci 62: 575-593

Farnsworth EJ, Ellison AM (1996) Scale-dependent spatial and temporal variability in biogeography of mangrove root epibiont communities. Ecol Monogr 66:45-66

Ferdeghini F, Acunto S, Cocito S, Cinelli F (2000) Variability at different spatial scales of a coralligenous assemblage at Giannutri Island (Tuscan Archipelago, northwest Mediterranean). Hydrobiologia 440:27-36

Gillanders BM, Kingsford MJ (2002) Impact of changes in flow of freshwater on estuarine and coastal habitats and the associated organisms. Oceanogr Mar Biol Annu Rev 40:233-309

Green RH (1979) Sampling design and statistical methods for environmental biologists. John Wiley \& Sons, New York

Green RH, Young RC (1993) Sampling to detect rare species. Ecol Appl 3:351-356

Guichard F, Bourget E (1998) Topographic heterogeneity, hydrodynamics, and benthic community structure: a scale dependent cascade. Mar Ecol Prog Ser 171:59-70

Healthy Rivers Commission of NSW (2002) Independent inquiry into coastal lakes: final report. Healthy Rivers Commission of NSW, Sydney

Hooper JNA, Kennedy JA (2002) Small-scale patterns of biodiversity in sponges (Porifera), from the Sunshine Coast, southeast Queensland. Invertebr Syst 16:637-653

Hooper JNA, Wiedenmayer F (1994) Porifera. In: Wells A (ed) Zoological catalogue of Australia. CSIRO Australia, Melbourne, p 1-621

Hooper JNA, Kennedy JA, Quinn RJ (2002) Biodiversity 'hotspots', patterns of richness and endemism, and taxonomic affinities of tropical Australian sponges (Porifera). Biodiversity Conserv 11:851-885

Kennelly SJ, Underwood AJ (1985) Sampling of small invertebrates on natural hard substrata in a sublittoral kelp forest. J Exp Mar Biol Ecol 89:55-67

Kennish MJ (2002) Environmental threats and environmental futures of estuaries. Environ Conserv 29:78-107

Keough MJ (1984) Effects of patch size on the abundance of sessile marine invertebrates. Ecology 65:423-437

Kovalak WP, Dennis SD, Bates JM (1986) Sampling effort required to find rare species of freshwater mussels. In: Isom BG (ed) Rationale for sampling and interpretation of ecological data in the assessment of freshwater ecosystems. ASTM STP 894, American Society for Testing and Materials, West Conshohocken, PA

Kuenen MMCE, Debrot AO (1995) A quantitative study of the seagrass and algal meadows of the Spaanse Water, Curacao, the Netherlands Antilles. Aquat Bot 51:291-310

Maldonado M, Young CM (1996) Effects of physical factors on larval behaviour, settlement and recruitment of four tropical demosponges. Mar Ecol Prog Ser 138:169-180

Matthiessen P, Law RJ (2002) Contaminants and their effects on estuarine and coastal organisms in the United Kingdom in the late twentieth century. Environ Pollut 120:739-757 
Morrisey DJ, Howitt L, Underwood AJ, Stark JS (1992) Spatial variation in soft-sediment benthos. Mar Ecol Prog Ser 81: 197-202

Moverley JH, Saenger P, Curtis MA (1986) Patterns of polychaete recolonization in Queensland subtropical estuaries following severe flooding. Hydrobiologia 134: 227-235

Pawlik JR (1998) Coral reef sponges: Do predatory fishes affect their distribution? Limnol Oceanogr 43:1396-1399

Pollard DA (1994a) Opening regimes and salinity characteristics of intermittently opening and permanently open coastal lagoons on the south coast of New South Wales. Wetlands 13:16-35

Pollard DA (1994b) A comparison of fish assemblages and fisheries in intermittently open and permanently open coastal lagoons on the south coast of New South Wales, Australia. Estuaries 17:631-646

Rader RB (1984) Factors affecting the distribution of a freshwater sponge. Freshw Invertebr Biol 3:86-97

Roberts DE (2001) Tuggerah Lakes estuary process study. Wyong Shire Council, Wyong

Roberts DE, Davis AR (1996) Patterns in sponge (Porifera) assemblages on temperate coastal reefs off Sydney, Australia. Mar Freshw Res 47:897-906

Roy PS, Williams RJ, Jones AR, Yassini I and 6 others (2001) Structure and function of south-east Australian estuaries. Estuar Coast Shelf Sci 53:351-384

Ruiz GM, Fofonoff P, Hines AH, Grosholz ED (1999) Nonindigenous species as stressors in estuarine and marine communities: assessing invasion impacts and interactions. Limnol Oceanogr 44:950-972

Rutzler K, Diaz MC, Van Soest RWM, Zea S, Smith KP, Alvarez B, Wulff J (2000) Diversity of sponge fauna in mangrove ponds, Pelican Cays, Belize. Atoll Res Bull 466-480:231-248

Sloss CR, Jones BG, Murray-Wallace CV, Chenall BE (2004) Recent sedimentation and geomorphological changes, Lake Illawarra, NSW, Australia. Wetlands 21:73-83

Stanley DJ, Warne AG (1993) Nile delta: recent geological evolution and human impact. Science 260:628-634

Underwood AJ (1981) Techniques of analysis of variance in experimental marine biology and ecology. Oceanogr Mar Biol Annu Rev 19:513-605

Underwood AJ (1997) Experiments in ecology: their logical design and interpretation using analysis of variance. Cambridge University Press, Cambridge

Editorial responsibility: Antony Underwood (Contributing Editor), Sydney, Australia
Underwood AJ, Chapman MG (1996a) Scales of spatial patterns of distribution of intertidal invertebrates. Oecologia 107:212-224

Underwood AJ, Chapman MG (1996b) Subtidal assemblages on rocky reefs at a cliff-face sewage outfall (North Head, Sydney Australia): What happened when the outfall was turned off? Mar Pollut Bull 33:293-302

Underwood AJ, Chapman MG (1998) Spatial analyses of intertidal assemblages on sheltered rocky shores. Aust J Ecol 23:138-157

Underwood AJ, Chapman MG (2003) Power, precaution, Type II error and sampling design in assessment of environmental impacts. J Exp Mar Biol Ecol 296:49-70

Underwood AJ, Petraitis PS (1993) Structure of intertidal assemblages in different locations: How can local processes be compared? In: Ricklefs RE, Schluter D (eds) Species diversity in ecological communities: historical and geographical perspectives. University of Chicago Press, Chicago, IL

Underwood AJ, Kingsford MJ, Andrew NL (1991) Patterns in shallow subtidal marine assemblages along the coast of New South Wales. Aust J Ecol 6:231-249

Underwood AJ, Chapman MG, Connell SE (2000) Observations in ecology: you can't make progress on processes without understanding the patterns. J Exp Mar Biol Ecol 250:97-115

West RJ, Jones MV (2000) Shallow water fish communities in New South Wales south coast estuaries. Final Report, Fisheries Research and Development Corporation, Canberra

West RJ, Walford TR, Williams RJ (1985) An estuarine inventory for New South Wales. NSW Department of Agriculture, Sydney

Wilkinson CR, Evans E (1989) Sponge distribution across Davies Reef, Great Barrier Reef, relative to location, depth and water movement. Coral Reefs 8:1-7

Winer BJ, Brown DR Michels KM (1991) Statistical principles in experimental design. McGraw-Hill, New York

Wulff JL (2000) Sponge predators may determine differences in sponge fauna between two sets of Mangrove Cays, Belize barrier reef. Atoll Res Bull 466-480:251-263

Zann LP (1995) Major findings of the state of the marine environment report for Australia. Great Barrier Reef Marine Park Authority, Townsville

Zea S (1993) Recruitment of demosponges (Porifera, Demospongiae) in rocky and coral reef habitats of Santa Marta, Colombian Carribean. PSZN I: Mar Ecol 14:1-21

Submitted: March 2, 2005; Accepted: November 25, 2005 Proofs received from author(s): June 18, 2006 